\title{
Effects of Different Plant Density and Cutting Times on Yield of Stevia under the Çukurova Conditions
}

\author{
L. Sezen TANSI ${ }^{* 1}$, Elnaz SAMADPOURRIGANI ${ }^{2}$, Selin GEDİK ${ }^{3}$, Amir SOLTANBEIGI ${ }^{2}$ \\ ${ }^{1}$ Çukurova University, Faculty of Agriculture, Department of Crop Fields, Adana \\ ${ }^{2}$ Afyon Kocatepe University, Ahmet Necdet Sezer Campus, Food Control Research and Application Center, \\ Afyonkarahisar
}

Received: 28 April 2017 - Revised: 12 August 2017 - Accepted: 11 September 2017

\begin{abstract}
Stevia (Stevia rebaudiana Bertoni) is perennial shrub form plant belonging to Asteraceae. It is indigenous to Paraguay and Brazil. Stevia is a natural sweetening and it has using potential to diets of obesity patients with non-caloric specialty and treatment of diabetes with insulin secretagogue specialty. In this study, the effects of different planting spaces and two cutting times on yields of two-year old Stevia plant were investigated. The highest dry leaf yield $(515.96 \mathrm{~kg} / \mathrm{da})$ was obtained from blooming stage, cuttings in spring and 30x60 cm planting density.
\end{abstract}

Keywords: Stevia rebaudiana, planting space, cutting times.

\section{INTRODUCTION}

Stevia rebaudiana (Bert.) Bertoni is a herbaceous perennial native to the high lands of Paraguay [1]. Four major glycosides such as stevioside A, rebaudioside A, rebaudioside C and dulcoside were the most important ones among eight glycosidic diterpenes found as sweetness in the leaves of wild Stevia [2]. Stevia is use wich as a wild commercial sweetener. It is also called as the sweet herb for these substances are 300 times sweeter than sucrose, used as caloriefree sweeteners $[6,8]$. Therefore, it has been used for the therapy such as diabetes, obesity and various diseases. Adaptation experiment of Stevia rebaudiana was started in recent years, although it was not found as wild plant in Turkey.The yield and quality of Stevia leaf were significantly affected by plant density and cutting time [4]. Also, growing and flowering of Stevia were affected day length, temperature, soil moisture and wind [6]. Therefore, in this research, the effect on yield of Stevia rebaudiana was studied different plant density and cutting time under the Çukurova conditions.

\section{MATERIAL and METHODS}

Seed material of stevia (Stevia rebaudiana) was provided from Paraguay. This study has been performed at the experimental area of Field Crops Department, Çukurova University Agriculture Faculty in 2013. Field trials were organized in the Complete Split-Plot Design with three replications. Effects of three different plant densities as mainplots $(30 \times 60,45 \times 60$ and

*Corresponding Author E-mail: Isezen@cu.edu.tr 
$60 \times 60 \mathrm{~cm}$, intra plant and row spacings) and ontogenetic variability as split-plot (such as pre and flowering stages) on yield and quality characteristics were investigated. Each plot has 7 rows, and each middle two rows were harvested at pre and flowering stages in May $12^{\text {nd }}$ and July $8^{\text {th }}, 2014$, respectively, the remaining edge rows were untouched to remove the side effects. Young seedlings were transplanted into field on April, $29^{\text {th }}, 2013$. Because the new plants have not grown sufficiently. The first year was adopted as the establishment period, so, data were excluded. The following year, new shots from the 1 year-old plants carefully managed and cuttings were performed and, necessary data were collected. Statistical analyses were performed by using MSTAT-C Statistical software [7].

\section{RESULTS and DISCUSSIONS}

While plant heights were significantly affected by both plant densities and cutting times number of stem values were significantly affected by plant densities. The highest plant values $(61.20 \mathrm{~cm})$ and number of stems (31.47 number plant $\left.{ }^{-1}\right)$ were obtained from the plant density with 30x60 spacing. Our findings were similar to [3] indicating narrow plant spacing's increased the both plant height $(71.11 \mathrm{~cm})$ and drug yields (Table 1). Considering the cutting times, the highest plant height was on cutting during the flowering. There were no significant differences among the number of stem depending on the cutting times

Table 1. The value of plant height and number of branches for plant density and cutting time under the Çukurova conditions.

\begin{tabular}{|c|c|c|c|c|c|c|c|c|}
\hline \multirow{3}{*}{$\begin{array}{c}\text { Cutting } \\
\text { times }\end{array}$} & \multicolumn{4}{|c|}{ Plant height $(\mathrm{cm})$} & \multicolumn{4}{|c|}{ Number of branches (numberplant ${ }^{-1}$ ) } \\
\hline & \multicolumn{4}{|c|}{ Plant density } & \multicolumn{4}{|c|}{ Plant density } \\
\hline & $30 \times 60$ & $45 \times 60$ & $60 \times 60$ & Mean & $30 \times 60$ & $45 \times 60$ & $60 \times 60$ & Mean \\
\hline Pre-flowering & 45.74 & 40.98 & 36.82 & $41.20 \mathrm{~b}$ & 29.83 & 26.75 & 20.83 & 25.81 \\
\hline Full-flowering & 78.09 & 70.45 & 64.80 & $71.11 \mathrm{a}$ & 33.10 & 23.57 & 18.77 & 25.14 \\
\hline Mean & $61.20 \mathrm{a}$ & $55.7 \mathrm{ab}$ & $50.80 \mathrm{~b}$ & & $31.47 \mathrm{a}$ & $25.16 \mathrm{ab}$ & $19.80 \mathrm{~b}$ & \\
\hline $\operatorname{LSD}_{(\% 5)}$ & \multicolumn{3}{|c|}{$\mathrm{LSD}_{\mathrm{pd}} 7.52$} & $\mathrm{LSD}_{\mathrm{ct}} 5.44$ & \multicolumn{4}{|c|}{$\mathrm{LSD}_{\mathrm{pd}} 8.39$} \\
\hline
\end{tabular}

In Stevia plants, according to the statistical analyses, main effects of plant densities and cutting times, and plant densities x cutting times interactions for fresh and dry herb, leaf yields were significant. The highest fresh herb yield (3002.48 $\left.\mathrm{kg} \mathrm{da}^{-1}\right)$ and dry herb yield $(1028.76 \mathrm{~kg}$ $\mathrm{da}^{-1}$ ) were obtained from the plant density with $30 \times 60 \mathrm{~cm}$ spacing at the harvest during the flowering (Table 2). The highest fresh leaf yield (1623.96 kg da-1) and dry leaf yield (515.96 $\mathrm{kg} \mathrm{da}^{-1}$ ) were obtained from the plant density with 30x60 cm spacing's at the spring harvest during the flowering (Table 3). 
Table 2. The Yields of Fresh Herb and Dry Herb of Stevia rebaudiana for plant density and cutting time under the Çukurova conditions.

\begin{tabular}{|c|c|c|c|c|c|c|c|c|}
\hline \multirow{2}{*}{$\begin{array}{l}\text { Cutting } \\
\text { times }\end{array}$} & \multicolumn{4}{|c|}{ Fresh herb yield $\left(\mathrm{kg} \mathrm{da}^{-1}\right)$} & \multicolumn{4}{|c|}{$\begin{array}{l}\text { Dry herb yield }\left(\mathrm{kg} \mathrm{da}^{-1}\right) \\
\text { Plant density }\end{array}$} \\
\hline & $30 \times 605 \times 60$ & 60x & 60 & Mean & $30 \times 60$ & $45 \times 60$ & $60 x 60$ & Mean \\
\hline Pre-flowering & $1316.89 \mathrm{c}$ & $656.77 \mathrm{e}$ & $373.94 \mathrm{e}$ & $782.54 \mathrm{~b}$ & $273.07 \mathrm{c}$ & $128.51 \mathrm{~d}$ & $81.87 \mathrm{~d}$ & $161.15 \mathrm{~b}$ \\
\hline Full-flowering & $3002.48 \mathrm{a}$ & $1658.96 \mathrm{~b}$ & $1003.9 \mathrm{~d}$ & $1888.45 \mathrm{a}$ & $1028.76 \mathrm{a}$ & $543.39 \mathrm{~b}$ & $343.63 \mathrm{c}$ & $638.59 \mathrm{a}$ \\
\hline Mean & $2159.69 a$ & $1157.87 \mathrm{~b}$ & $688.92 \mathrm{c}$ & & $650.92 \mathrm{a}$ & $335.95 \mathrm{~b}$ & $212.75 \mathrm{~b}$ & \\
\hline $\operatorname{LSD}_{(\% 5)}$ & $\operatorname{LSD}_{\text {pd }} 367.91$ & $1 \mathrm{LSD}_{\mathrm{ct}} 167.8$ & $7 \mathrm{LSD}_{\text {pdxct }} 2$ & & $\operatorname{LSD}_{\mathrm{pd}} 140$. & $013 \operatorname{LSD}_{\mathrm{ct}} 81$ & 31.147 $\mathrm{LSD}_{\mathrm{pdx}}$ & 140.55 \\
\hline
\end{tabular}

Table 3. The Yields of Fresh Leaf and Dried Leaf of Stevia rebaudiana for plant density and cutting time under the Çukurova conditions.

\begin{tabular}{|c|c|c|c|c|c|c|c|c|}
\hline \multirow{3}{*}{ Cutting times } & \multicolumn{4}{|c|}{ Fresh leaf yield $\left(\mathrm{kg} \mathrm{da}^{-1}\right)$} & \multirow{2}{*}{\multicolumn{4}{|c|}{$\begin{array}{c}\text { Dry leaf yield }\left(\mathrm{kg} \mathrm{da}^{-1}\right) \\
\text { Plant density }\end{array}$}} \\
\hline & \multicolumn{4}{|c|}{ Plant density } & & & & \\
\hline & $30 \times 60$ & $45 \times 60$ & $60 \times 60$ & Mean & $30 \times 60$ & $45 \times 60$ & $60 \times 60$ & Mean \\
\hline Pre-flowering & $829.05 \mathrm{~b}$ & $366.24 \mathrm{~cd}$ & $250.35 \mathrm{~d}$ & $481.88 \mathrm{~b}$ & $184.65 \mathrm{c}$ & $84.17 \mathrm{~d}$ & $56.47 \mathrm{~d}$ & $108.43 \mathrm{~b}$ \\
\hline Full-flowering & $1623.96 \mathrm{a}$ & $938.43 \mathrm{~b}$ & $562.07 \mathrm{c}$ & $1041.49 \mathrm{a}$ & $515.96 \mathrm{a}$ & $297.56 \mathrm{~b}$ & $190.69 \mathrm{c}$ & $334.74 \mathrm{a}$ \\
\hline Mean & $1226.51 \mathrm{a}$ & $652.34 \mathrm{c}$ & $812.42 \mathrm{~b}$ & & $350.31 \mathrm{a}$ & $190.87 \mathrm{~b}$ & $123.58 \mathrm{c}$ & \\
\hline $\operatorname{LSD}_{(\% 5)}$ & \multicolumn{4}{|c|}{ 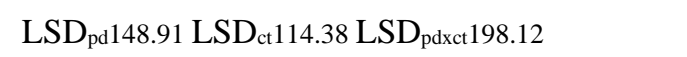 } & \multicolumn{4}{|c|}{$\mathrm{LSD}_{\mathrm{pd}} 56.087 \mathrm{LSD}_{\mathrm{ct}} 35.94 \mathrm{LSD}_{\mathrm{pdxct}} 62.25$} \\
\hline
\end{tabular}

\section{CONCLUSION}

Because the plants showed best performance in the second year due to good adaptation to environmental condition the better yields were obtained at the plots with narrow plants spacing in the both harvests done in spring and summer season. Leaf yield were higher during flowering. As the plant continue to grow from vegetative to generative stage. According to the result obtained from the research, it has been indicated that stevia plants can be successfully grown. Also, there were morphological difference among the seedling from seeds directly. Further research is need to select the best seedlings and to determine the yield and quality characteristics.

\section{Conflict of Interests}

Authors declare that there is no conflict of interests.

\section{REFERENCES}

[1] Brandle, J. E., \& Rosa, N. (1992). Heritability for yield, leaf: stem ratio and stevioside content estimated from a landrace cultivar of Stevia rebaudiana. Canadian Journal of Plant Science, 72(4), 1263-1266.

[2] Kinghorn A.D. (2002). (ed.): Stevia, the Genus Stevia. - Taylor and Francis, London - New York.

[3] Kumar, R., Sood, S., Sharma, S., Kasana, R. C., Pathania, V. L., Singh, B., \& Singh, R. D. (2014). Effect of plant spacing and organic mulch on growth, yield and quality of natural sweetener plant Stevia and soil fertility in western Himalayas. Int J Plant Prod, 8(3), 311334. 
[4] Serfaty, M., Ibdah, M., Fischer, R., Chaimovitsh, D., Saranga, Y., \& Dudai, N. (2013). Dynamics of yield components and stevioside production in Stevia rebaudiana grown under different planting times, plant stands and harvest regime. Industrial crops and products, 50, 731-736.

[5] Soejarto, D. (2002). Botany of Stevia and Stevia rebaudiana, In A. Kinghorn (Ed.), Stevia: The genus Stevia (pp. 18-39). London, New York: Taylor and Francis.

[6] Ramesh, K., Singh, V., \& Megeji, N. W. (2006). Cultivation of stevia [Stevia rebaudiana (Bert.) Bertoni]: A comprehensive review. Advances in Agronomy, 89, 137-177.

[7] Steel, R.G.D., \& Torrie, J.H. (1980). Principles and Procedures of Statistics. A biometrical approach. 2nd edition, McGraw-Hill, New York, USA, pp. 20-90.

[8] Tavarini, S., \& Angelini, L. G. (2013). Stevia rebaudiana Bertoni as a source of bioactive compounds: the effect of harvest time, experimental site and crop age on steviol glycoside content and antioxidant properties. Journal of the Science of Food and Agriculture, 93(9), 2121-2129. 